ENTREPRENEURSHIP AND SUSTAINABILITY ISSUES

ISSN 2345-0282 (online) http://jssidoi.org/jesi/

2020 Volume 7 Number 3 (March)

http://doi.org/10.9770/jesi.2020.7.3(48)
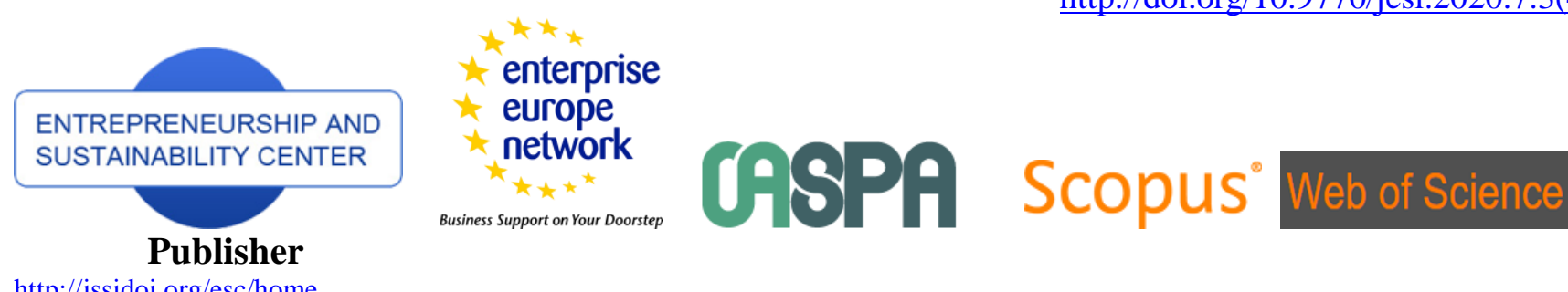

http://jssidoi.org/esc/home

\title{
MAIN TRENDS OF GOVERNMENT REGULATION OF SECTORAL DIGITALIZATION
}

\author{
Andrei V. Glotko ${ }^{1 *}$, Aleksandra G. Polyakova ${ }^{2}$, Mariya Yu. Kuznetsova ${ }^{3}$, Kseniya E. Kovalenko ${ }^{4}$, \\ Rustem A. Shichiyakh ${ }^{5}$, Margarita V. Melnik ${ }^{6}$ \\ 1* Gorno-Altaisk State University, Lenkin Street, 1, Gorno-Altaisk, 649000, Russian Federation \\ ${ }^{2}$ Plekhanov Russian University of Economics, Stremyanny lane, 36, 117997, Moscow, Russian Federation \\ ${ }^{2}$ Industrial University of Tyumen, Volodarskogo Street, 38, 625000, Tyumen, Russian Federation \\ ${ }^{3}$ Sechenov First Moscow State Medical University, 119991, Moscow, Trubetskaya Str., 8-2, Russian Federation \\ ${ }^{4}$ Altai State University, Lenin Ave., 61, 656049, Barnaul, Russian Federation \\ ${ }^{4}$ Ural State Law University, Russian Federation, 620137, Yekaterinburg, Komsomolskaya St., 21, Russian Federation \\ ${ }^{5}$ Kuban State Agrarian University named after I.T. Trubilin, 350044, Krasnodar, Kalinina Str. 13, Russian Federation \\ ${ }^{6}$ Financial University under the Government of the Russian Federation, 125993, Leningradsky Prospekt, 49, Moscow, \\ Russian Federation \\ E-mails: ${ }^{{ }^{*}}$ ganiish_76@mail.ru
}

Received 12 June 2019; accepted 10 January 2020; published 30 March 2020

\begin{abstract}
This paper examines the principal trends of the government regulation of the milk-producing industry. It focuses on the rationale of those trends for improving the government regulation of dairy industry parameters and the development of effective methods for their implementation in the context of transformation into the digital economy. The study explores theoretical positions, approaches, and principles of the government regulation of digitalization of the dairy industry. It also identifies the essence and forms of this regulation. The researchers developed an economic and mathematical model of the relationship between the dairy industry parameters through a multilevel chain of indirect parameter relationship. The researchers also worked out the methodological foundations for modeling the dairy industry using digital technologies. A reverse forecasting technique was developed to estimate the necessary volume of the government support required to achieve dairy industry target indicators at any level of regulation. The model was tested with various scenarios for forecasting the results of the government regulation of the dairy industry in order to achieve the target criteria.
\end{abstract}

Keywords: digital economy; government regulation efficiency; digital models; forecasting technique

Reference to this paper should be made as follows: Glotko, A. V., Polyakova, A. G., Kuznetsova, M. Y., Kovalenko, K. E., Shichiyakh, R. A., Melnik, M. V. 2020. Main trends of government regulation of sectoral digitalization. Entrepreneurship and Sustainability Issues, 7(3), 2181-2195. http://doi.org/10.9770/jesi.2020.7.3(48)

JEL Classifications: Q16, Q18

\section{Introduction}

In terms of the gross agricultural output, the Russian Agro-Industrial Complex (AIC), which includes the dairy industry, sufficiently large. As of 2018, the Russian Federation produces about 32 million tons of milk (including 


\section{ENTREPRENEURSHIP AND SUSTAINABILITY ISSUES}

ISSN 2345-0282 (online) http://jssidoi.org/jesi/

2020 Volume 7 Number 3 (March)

http://doi.org/10.9770/jesi.2020.7.3(48)

the marketable milk comprising more than 22 million tons) of milk per year, which provides up to $83 \%$ of the population's need for milk and dairy products. Despite a rather high level of overall food security achieved in the country - surpassing the targets of the Doctrine of Food Security of the Russian Federation in most positions, the dairy industry turns out to be a bitter exception. According to the Doctrine of Food Security, the country must produce milk (and dairy products equivalent to milk) to a level of at least 90\% (Tultabayeva et al., 2017, 2019; Almeida et al., 2019). Taken together, the insufficient government support of livestock industries, as the raw material basis of domestic food production, and the insignificant expansion of the country's export potential result in low levels of both production efficiency and technical equipment in most agricultural enterprises, especially within the dairy industry (Tikhonov et al., 2019).

A low production efficiency of milk and dairy products negatively affects the quality of life of the country's population. In the pre-reform period, the dairy industry in Russia completely met the population's need for milk and dairy products at the level of medical standards. At present, and at the current rate of consumption, the level of self-sufficiency in milk and dairy products of the population of the Russian Federation (RF) is $70 \%$; in the Siberian Federal District (SFD), it is $75 \%$. There is also a decreasing trend of milk and dairy product consumption per capita of about 1\% annually (in the Russian Federation from 75\% in 2014 to 70\%, and in the Siberian Federal District from $79 \%$ to $75 \%$ ).

To eliminate these negative tendencies, urgent measures are needed to strengthen the government support and stimulation of the dairy industry, primarily because of its effective transformation into the digital economy (DE) (Sharafutdinov et al., 2019; Sycheva et al., 2019; Petrenko et al., 2019; El Idrissi et al., 2020). Therefore, the need to develop theoretical principles and practical recommendations for improving the process of the government regulation of the dairy industry in the context of its transformation into the DE determines the relevance of the study.

\section{Literature review}

An analysis of the scientometric databases of the RSCI and WoS shows that more than $20 \%$ of the research on the problems of the agro-industrial complex is related to the dairy industry. This indicates its importance and the rationale of choosing it as a study object. At the same time, there are practically no works devoted to the regulation of the dairy industry in the context of digitalization. Only one publication in the RSCI (Kudryashov, 2019) and one publication in the WoS (Hansen, 2019) consider these particular problems. Since the dairy industry is developing in almost all countries of the world as well as in the regions like the Russian Federation and its territorial entities, the Novosibirsk region, which is in the center of the Siberian District, was chosen as an object of the research. The chosen research topic is characterized by three keywords: the dairy industry, regulation, and digitalization.

Digitalization (digital transformation) is most often understood as a change in the form of doing business in digital reality based on data (Yandex Zen, 2019; Prodani et al., 2019). "The digital economy is an environment that includes a combination of digital infrastructure and innovative diversification of information and communication technologies for doing business" (Chernyakov, 2016). Considering the transition of the agroindustrial complex to the DE, the research should rely on the following definition: "the government regulation in agriculture is the real-time economic impact of authorities using digital support for the production, processing, and the sale of agricultural products, raw materials and food, agricultural infrastructure" (Chernyakova, 2019). Taking into account the industry specifics of the dairy subcomplex, the following definition can be given: "Regulation of the dairy industry in the context of digitalization is the real-time economic impact of authorities using digital support for the production of milk, milk processing, and the sale of milk and dairy products, on the infrastructure of the dairy sub-complex." 


\section{ENTREPRENEURSHIP AND SUSTAINABILITY ISSUES}

ISSN 2345-0282 (online) http://jssidoi.org/jesi/

2020 Volume 7 Number 3 (March)

http://doi.org/10.9770/jesi.2020.7.3(48)

Based on various sources of information (Sysuev et al, 2017; Bobkova et al., 2015; Petrik and Oshakbaev, 2015; Pavlyshyn et al., 2019; Rahman, 2017), a system for the development of organizations of the dairy sub-complex of the agro-industrial complex was proposed, which is a closed system consisting of four main elements: causes, goals, functions, and principles of the government regulation of the dairy industry. All of the listed components of the system elements are tentative, not constant, and changing their components requires adjustments of other elements (one or more). Consequently, the system is changing dynamically, and the task of the regulation is to determine the vector of these changes (Hirdinis, 2019; Movchan and Yakovleva, 2019; Ermakova et al., 2016; Dunets et al., 2019; Regaña et al., 2019).

Badalyan M.E. in his study suggests that the system of the government regulation of the dairy industry should be formed in such a way that the regulation should use the paradigm of the "efficient core activity" (Badalyan, 2013) through a clear formulation of the goals of the activities and the choice of more effective means of their implementation. To increase the efficiency of using digital technologies in the dairy industry, it is necessary to 1) introduce innovative technological processes for the production of milk and dairy products and 2) improve the information and technology support for managing these processes (Chernyakov and Chernyakova, 2015).

Agricultural production is developing along the path of automation and computerization (Burda, 2018) including such innovations as electronic herd management systems. Internet of things (IoT) solutions developed in the Russian Federation such as the Rightech IoT Cloud and the kSense IoT platforms can provide for, among other things, livestock management. Thanks to these platforms, farmers can track livestock location, monitor pregnant and sick animals, determine rational milking times, etc. There is a continual improvement of this new technology, and farmers show a great interest in obtaining it; however, only $3-5 \%$ of the country's dairy farms have introduced comprehensive automation of herd management (Surovtsev and Nikulina, 2019).

Integrating DE technologies into the dairy industry can reduce the costs by at least $23 \%$ (Livestock industry ..., 2019). According to the experts of the PwC group ( $\mathrm{PwC}$ is the largest audit network), the major challenges for Russian farmers include the growth of domestic and foreign demand for agricultural products as well as the need to increase labor productivity and competitiveness. These challenges will inevitably be a driving force for the technological development of the dairy industry. On November 27, 2018 at the Fifth International Agro-Industrial Dairy Forum, a session was held on the "Digital Agenda of the Dairy Industry" (Ministry of Agriculture of the Russian Federation, 2018). It was attended by Irina Ganieva, who is the Director of the Department of Digital Development and Management of State Information Resources of the Agro-Industrial Complex of the Ministry of Agriculture of Russia. Ganieva introduced the departmental project "Digital Agriculture" (Departmental Project "Digital Agriculture," 2019). Its goal is to provide a technological breakthrough in the agricultural sector through the introduction of digital technologies in agriculture. It is assumed that this change will have doubled the labor productivity in agricultural enterprises by 2021 .

One of the stages of the project implementation will be the creation of the Intellectual system of government support measures (Korableva et al., 2018). Integration with the databases of the Russian Meteorological Service and the Ministry of Emergencies will allow for the adjustment of subsidies for the introduction of emergencies in the regions. It is planned that by 2021, $100 \%$ of contracts with recipients of the government support will have been made in the electronic form. By the same time, all agricultural products for export will have been accompanied by a paperless system "from field to port."

According to the research from the Ministry of Agriculture of the Russian Federation, the introduction of digital economy technologies provides positive economic effects and can reduce the costs by at least $23 \%$ as well as increase agricultural production by 361.4 billion rubles when an integrated approach is followed (Kokova, 2019). 


\section{Theoretical background}

The Strategy for Spatial Development of the Russian Federation identifies the most important and promising areas of effective economic specialization of the Novosibirsk region directly related to the dairy industry for the period up to 2025:

1. Crop production and livestock, provision of appropriate services in these areas,

\section{Food production,}

\section{Beverage production.}

The Novosibirsk region shows stable positive dynamics in increasing the production of milk and dairy products per capita, which allowed it to rise in the all-Russian ranking of regions in terms of production from the 14th place in 2014 to the 11th place in 2018 and in terms of consumption from the 11th place in 2014 to the 4th place in 2018. The region's share of total Russian milk production also increased significantly from 2014 to 2018 by $0.2 \%$ including the market share by $0.3 \%$ and reached $2.3 \%$ and $2.7 \%$ respectively. The success of the Novosibirsk region in developing the dairy industry and providing the population with these products is fully correlated with the regulatory impacts of the government support for this industry in the region. The comparison of the data for 2014-2017 does not show a close linear relationship (the correlation coefficient of 0.58) between the volume of government support funds for the dairy industry and the volume of milk produced in the Novosibirsk region, which indicates the complexity of the regulatory impact on the main industry indicator. This necessitates a thorough study of the nature of such an impact in order to find an opportunity to manage it (Yemelyanov et al., 2018).

An assessment of the effect of digital technologies on the parameters of the dairy industry revealed a correlation close to linear between the number of microchipped cattle and daily milk production per cow and gross milk production. The effect of the number of chipped cows $(\mathrm{X})$ on the productivity $(\mathrm{Y})$ is approximated by the following expression:

$\mathrm{Y}=0,0072 * \mathrm{X}+13,164$

The use of digital technologies in dairy cattle breeding ensures the increase in labor costs for obtaining a centner of milk up to one person-hour and increase in profitability up to $40 \%$ (Gritsenko et al, 2019). In order to provide the population of the Novosibirsk region with high-quality products, the following tasks are set for agricultural producers of the Novosibirsk region:

1. Enhance productivity of dairy cattle through the use of digital technologies, attracting the best global genetics and significantly increasing output.

2. Create a competitive breeding base, increasing not only the number of breeding animals (up to $25 \%$ of the specific gravity), but also the milk quality (milk production up to $9600 \mathrm{~kg}$ in breeding organizations).

3. In the framework of the federal project "Export of Agricultural Products," ensure that milk production in farms of all categories will have reached the amount of 733 thousand tons by 2024 . 


\section{ENTREPRENEURSHIP AND SUSTAINABILITY ISSUES}

ISSN 2345-0282 (online) http://jssidoi.org/jesi/

2020 Volume 7 Number 3 (March)

http://doi.org/10.9770/jesi.2020.7.3(48)

Achieving the tasks at hand is impossible without the effective transformation of the dairy industry into the DE. To implement the transformation process, it is necessary to develop effective models, mechanisms, and technologies to predict the necessary events to fulfill these tasks. Using the synergistic effect means to hypothesize the existence of a multilevel model of a stepwise interaction of the relationship between the regulatory effect and the parameters of the dairy industry that do not have a direct functional relationship with it. These parameters have a closer relationship not with the regulator, but with the intermediate indicators, and are dependent on it indirectly. The novelty of the hypothesis is that the correlation coefficient between the regulator and indirect indicators may be close to zero, but the results will show a high degree of accuracy in their calculation.

The implementation procedure (algorithm) of the proposed hypothesis in the form of a multi-level model of a stepwise interaction is shown in Figure 1.

1. The "Initial data" block (Fig. 1) contains the information on the number of the parameters under study $(\mathrm{K})$, time periods analysis $(\mathrm{P})$, and the matrix $\mathrm{X}(\mathrm{K}, \mathrm{P})$ of the values of each parameter in time intervals. In the "Regulator selection" block, a parameter (one or several) is assigned, the influence of which on other indicators is to be analyzed.

2. After the initial data input, a correlation analysis of the matrix $X(K, P)$ is performed. The values of the correlation coefficients of the regulator are removed from the correlation matrix and ranked relative to other indicators in descending order.

3. Then the model level is calculated. By default, in the initial state, the level is equal to zero. As a result, we obtain: $U=0+1=1$ for the first level of (direct) influence, $U=1+1=2$ for the second level of (indirect) influence, etc.

4. Then, a cycle is started to select indicators that are significant for a given level. The indicators are excluded from the matrix of values, and the regression coefficients are determined for their dependence on the regulator (direct, indirect first level, etc.). The cycle is repeated until an indicator appears, for which the criterion of restriction is less than the specified one.

5. In the case of $\mathrm{R}<0.5$, the number of untested parameters is analyzed. If $\mathrm{K}>0$, then the indirect regulator of the U-level is selected according to the criterion of the highest correlation coefficient from the significant indicators of the level $\mathrm{R} \Rightarrow$ max. The algorithm proceeds to the analysis of the next level of the model and the process is repeated from stage 3 .

6. In the reverse situation $(K=0)$, the mechanism completes its work, and the result in the form of mathematical dependencies can be used for further analysis, modeling, and forecasting.

7. The proposed approach does not deny fundamental laws, theories, hypotheses, or mechanisms, but organically uses and improves them, which makes it possible to use the developed mechanisms as universal in the study of the parameters of the dairy industry, for example, in combination with the simulation mod 


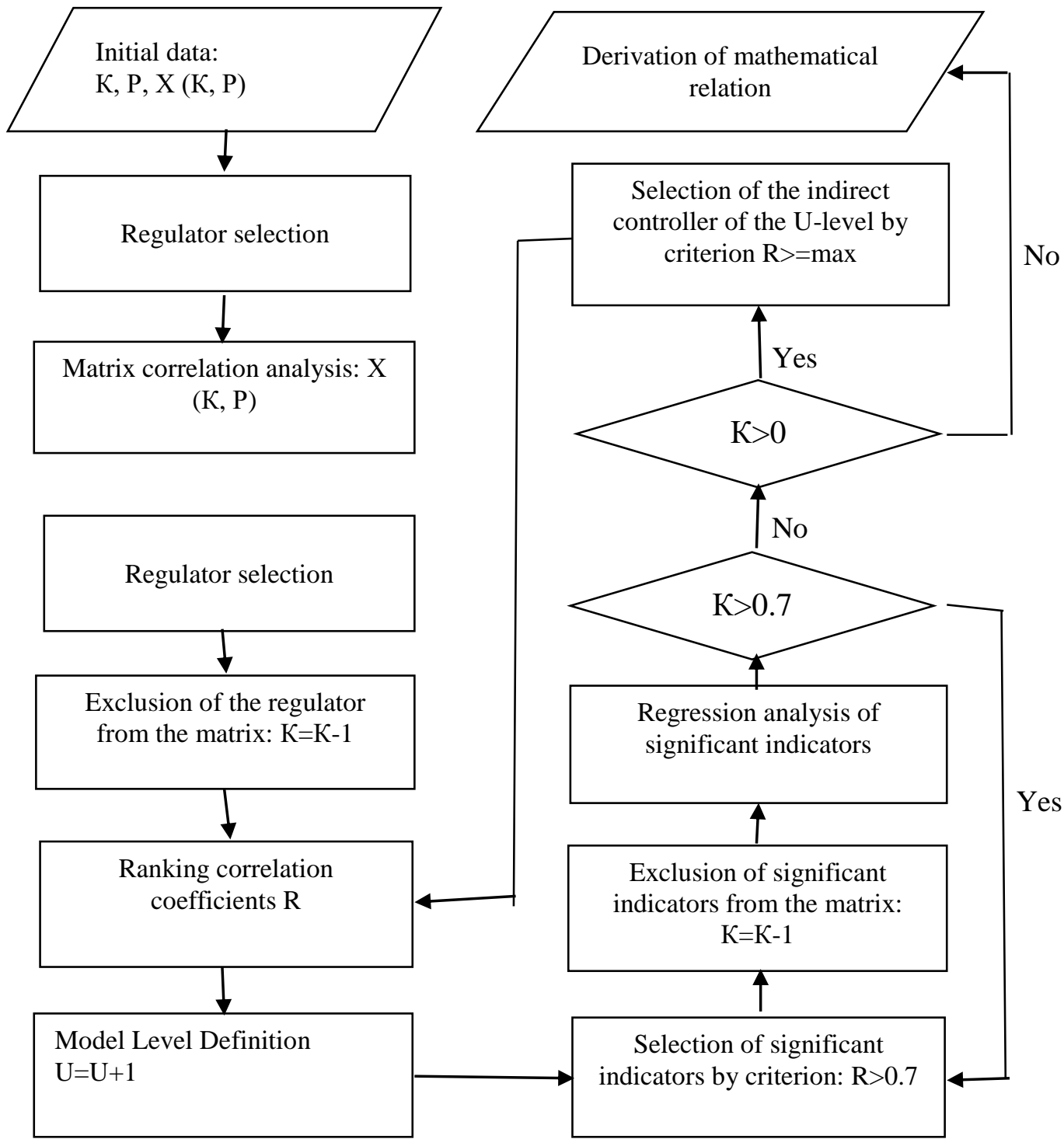

Figure 1. Algorithm for modeling the relationship of parameters for government regulation of the dairy industry Source: Glotko et al, 2019

\section{Data analysis}

The algorithm based on the formulas in the form of the mathematical support of a digital model is substantiated. It is proposed to use the regulatory instrument in the form of the government support as the source data in the proposed algorithm, the management of which makes it possible to achieve necessary indicators of the dairy industry. It is also proposed to use the volume of government support funds for the dairy industry as a regulatory impact. 


\section{ENTREPRENEURSHIP AND SUSTAINABILITY ISSUES}

ISSN 2345-0282 (online) http://jssidoi.org/jesi/

2020 Volume 7 Number 3 (March)

http://doi.org/10.9770/jesi.2020.7.3(48)

After checking the correctness of the initial data input, the Information and Communication Technologies conduct an analysis and calculation of indicators of the direct influence of the first level. Having calculated the specific parameters and inserting them into the database, the algorithm proceeds to the next step.

The next step is the calculation of indicators of the indirect influence of the second level, based on the results of the calculation of the most significant parameters of the direct influence of the first level. At this step, the indicators that become the source data for the third calculation step are calculated. At the third step, using the most significant parameters of the second step, the final indicators are determined. At the final step, the calculation results are included in a database and can be transferred to the relevant ICT users in an electronic or paper form.

An action plan was developed in accordance with the proposed hypothesis, which ensured using the digital data taken from the open sources to develop digital models of the dairy industry in the Novosibirsk region. The study of the three-level model algorithm was carried out on the basis of the actual data of the Novosibirsk region during 2014-2018.

As a result of the prior study, a three-level model of the influence of the controlling parameter of the government regulation (the amount of government support funds for the dairy industry) on the quantitative and qualitative indicators of the Novosibirsk region industry was proposed.

The first level (direct impact) includes two indicators: the number of cows at the end of the year in agricultural enterprises (AE) and peasant farms (PF) and milk production of breeding cows. This indicates that the regulator stimulates not only a quantitative increase in the herd from the emphasis on breeding cows, but also on a qualitative increase in its milk productivity.

The second level (indirect influence) includes eight indicators: milk production on the farms of all categories including marketable milk, the share of pedigree cows in collective farms, peasant farms, and private farms including dairy and mixed production directions, milk productivity of cows in the farms of all categories including agricultural enterprises and peasant farms, the production of milk and dairy products per capita, for which the regulator does not have a direct strong impact, but they are strongly influenced by the indicators of the first level and, most of all, by the number of cows at the end of the year in the agricultural enterprises and farms.

The third level (secondary indirect influence) includes four indicators that are almost independent of the regulator (the correlation coefficient varies from -0.33 to 0.26 ) and of the indicators of the first level (the correlation coefficient varies from -0.71 to 0.26), and these third-level indicators have multidirectional vector manifestations. They have a strong interdependence with only some indicators of the second level. In particular, the consumption of milk and dairy products per capita and the milk productivity of cows in private households are most dependent on the production of milk and dairy products per capita (the correlation coefficient makes up more than 0.55), whereas the indicator of milk processing and dairy production in terms of milk is significantly determined by the production of marketable milk (the correlation coefficient makes up -0.81), but it has a paradoxical opposite tendency - with an increase in milk production, its processing in the Novosibirsk region decreases.

Due to the reduction in prices associated with its large production in the region, milk is exported to the neighboring regions: the Altai Territory and Omsk region, which have efficient milk processing enterprises. An unexpected outcome was obtained as a result of the analysis of the number of cows on the farms of all categories at the end of the year. Its strong relationship was recorded exclusively with the parameters of milk processing and milk production in terms of milk (the correlation coefficient of 0.74 ). 
The final results of the multilevel correlation and regression analyses are shown in Table 1. It shows that the error of the obtained mathematical equations does not exceed $9 \%$, which indicates the possibility of using the proposed mathematical tools as a mechanism for predicting the effects of the government regulation on the main indicators of the dairy industry of the Novosibirsk region.

The validity check of the digital model in comparison with the actual data for the previous five years shows that with the smallest relative deviation (less than 2\%) the last indicator X3 in the algorithm (the number of cows on the farms of all categories at the end of the year) is calculated, and with the largest (slightly more than 20\%) - X6 (the share of breeding cows of the dairy and mixed directions of productivity).

Table 1. Interdependence between the volume of government support funds for the dairy industry of the Novosibirsk region and its main indicators

\begin{tabular}{|c|c|c|c|}
\hline Designation & Digital model & Correlation coefficient & Error, $\%$ \\
\hline Level 1 & Direct influence & & \\
\hline $\mathrm{X} 4$ & $\mathrm{X} 4=0,009878 * \mathrm{X} 15+134,186$ & 0,87 & Less than $2,5 \%$ \\
\hline $\mathrm{X} 11$ & $\mathrm{X} 11=1,388184 * \mathrm{X} 15+7187,9351$ & 0,73 & Less than $8,3 \%$ \\
\hline Level 2 & Indirect influence & & \\
\hline $\mathrm{X} 1$ & $\mathrm{X} 1=6,634324 * \mathrm{X} 4-255,723$ & 0,88 & Less than $3,2 \%$ \\
\hline $\mathrm{X} 2$ & $X 2=10,37241 * X 4-949,852$ & 0,82 & Less than $8,2 \%$ \\
\hline $\mathrm{X} 5$ & $\mathrm{X} 5=0,467732 * \mathrm{X} 4-51,2205$ & 0.89 & Less than $8,8 \%$ \\
\hline X6 & $\mathrm{X} 6=0,492792 * \mathrm{X} 4-56,2171$ & 0,89 & Less than $1,7 \%$ \\
\hline $\mathrm{X} 7$ & $\mathrm{X} 7=58,20987 * \mathrm{X} 4-4410,82$ & 0,90 & Less than $4,6 \%$ \\
\hline $\mathrm{X} 8$ & $\mathrm{X} 8=76,64832 * \mathrm{X} 4-6569,93$ & 0,89 & Less than $5,7 \%$ \\
\hline X9 & $X 9=49,55294 * X 4-4141,81$ & 0,90 & Less than $5,2 \%$ \\
\hline $\mathrm{X} 12$ & $\mathrm{X} 12=1,64969 * \mathrm{X} 4-42,404$ & 0,81 & Less than $7,5 \%$ \\
\hline Level 3 & Secondary indirect influence & & \\
\hline $\mathrm{X} 10$ & $\mathrm{X} 10=5,891 * \mathrm{X} 12+1738,445$ & 0,69 & Less than $2,4 \%$ \\
\hline $\mathrm{X} 13$ & $\mathrm{X} 13=0,5063 * \mathrm{X} 12+186,7629$ & 0,55 & Less than $4,2 \%$ \\
\hline $\mathrm{X} 14$ & $\mathrm{X} 14=-164,429 * \mathrm{X} 2+251345,285$ & $-0,81$ & Less than $7 \%$ \\
\hline $\mathrm{X} 3$ & $\mathrm{X} 3=0,00017 * \mathrm{X} 14+162,947927$ & 0,74 & Less than $1,2 \%$ \\
\hline
\end{tabular}

Legend:

Source: own research

$\mathrm{X} 1$ - Milk production on farms of all categories, thousand tons

$\mathrm{X} 2$ - Production of commercial milk, thousand tons

$\mathrm{X} 3$ - The number of cows on farms of all categories at the end of the year, thousand heads

$\mathrm{X} 4$ - Cows at year-end in AO, peasant farms, PSP, thousand heads

X5 - The proportion of breeding cows in AO, peasant farms, PSP, \%

X6 - The share of breeding cows of dairy and mixed directions of productivity, $\%$

$\mathrm{X} 7$ - Dairy productivity of cows in farms of all categories, $\mathrm{kg} /$ year

$\mathrm{X} 8$ - Dairy productivity of cows in agricultural organizations (AO), $\mathrm{kg} /$ year

$\mathrm{X} 9$ - Dairy productivity of cows in peasant farms (peasant farms), $\mathrm{kg} /$ year

X10 - Milk productivity of cows in personal subsidiary plots (PSP), $\mathrm{kg} /$ year

X11 - Milk productivity of breeding cows, $\mathrm{kg} /$ year

$\mathrm{X} 12$ - Production of milk and dairy products per capita, $\mathrm{kg} / \mathrm{year}$

$\mathrm{X} 13$ - Consumption of milk and dairy products per capita, $\mathrm{kg} /$ year

$\mathrm{X} 14$ - Milk processing and production of dairy products in terms of milk, tons

X15 - The volume of state support funds for the dairy industry, million rubles 


\section{ENTREPRENEURSHIP AND SUSTAINABILITY ISSUES}

ISSN 2345-0282 (online) http://jssidoi.org/jesi/

2020 Volume 7 Number 3 (March)

http://doi.org/10.9770/jesi.2020.7.3(48)

\section{Results}

The mathematical model developed on the basis of the synergistic approach was the basis for the formation of tools for direct and reverse forecasting of milk production and performance indicators of the dairy industry in the region. The direct forecast of indicators of the dairy industry in the region, in contrast to the existing tools, is based on the use of not only a time factor, but also on the amount of government support funds. It provides an opportunity to predict the performance of the dairy industry depending on the amount of the government support. The reverse forecast solves the problem of determining the necessary amount of the government support to achieve the target indicators of the dairy industry at any level of regulation. The application of the proposed tools enables regional authorities to form intersectoral relations in the dairy industry. The effective formation of intersectoral mutual relations becomes possible thanks to the technical equipment and software of the processes of the government regulation of digitalization in the dairy industry.

The forecasting results for 2019 show that a decrease in the government support could lead to a degradation of the dairy industry in the Novosibirsk region. Keeping financing at the same level can only slow down its decline. This indicates an acute current underfunding of the dairy industry by state authorities. The situation may change for the better with an increase in government support funds by at least twice compared to the ongoing funding.

To achieve the recommended rational consumption rate (of milk and dairy products in total equivalent to milk) $325 \mathrm{~kg} /$ year / person, the government support funds in the amount of 5,773 million rubles will be required. As a result, this will lead to an increase in the annual production of milk and dairy products per capita up to $273 \mathrm{~kg} /$ person and an increase in the heads of cows by 46 thousand at the end of the year in agricultural enterprises, peasant farms, and private farms. It is unlikely to achieve such a result in one year, so the calculated amount of funds will have to be distributed over several years.

With the optimistic development of the scenario, it will be possible to achieve the recommended rational consumption rate (of milk and dairy products in total equivalent to milk) in the Novosibirsk region not earlier than in four years, but with the expected - in 8 years. However, the estimated time frame will vary depending on the actual amount of government support funds allocated. The mathematical model enables to make appropriate adjustments depending on the regulatory influences. If we exclude from the calculations the factor of regulatory influence depending on the amount of the government support and leave only the time factor, then it will be possible to achieve the recommended rational consumption rate (of milk and dairy products in total equivalent to milk) in the Novosibirsk region not earlier than in 30 years (a pessimistic option).

Providing the population with dairy products in accordance with medical consumption standards in the region implies an increase in the effective growth of all parameters of the dairy industry, which can be achieved only with the use of digital technologies, which make it possible to predict the steps of an effective regulatory impact depending on the amount of government support funds. Without the government support and determining its adequate amount, the development of the dairy industry is unlikely.

\section{Discussion}

Based on various sources of information, the researchers suggest using a system for the development of organizations in the dairy industry of the agro-industrial complex, which represents a closed system consisting of four main elements: causes, goals, functions, and principles of the government regulation of the dairy industry (Frolova et al., 2019; Trofimova et al., 2019). The essential structure of the functioning system is a chain, the first link of which is the sphere of agriculture, the second one is industry, and the final one is services (Safiullin and Akhmetshin, 2019; Murtazina et al., 2018; Plotnikov et al., 2018). It is proposed to consider the essential model of 


\section{ENTREPRENEURSHIP AND SUSTAINABILITY ISSUES}

ISSN 2345-0282 (online) http://jssidoi.org/jesi/

2020 Volume 7 Number 3 (March)

http://doi.org/10.9770/jesi.2020.7.3(48)

the digitalization system of the government regulation of the dairy industry as a closed system consisting of three elements: government regulation, digitalization, and parameters of the industry itself.

Perhaps, in the process of shaping the system of the government regulation of the dairy industry, it will be necessary to abandon some of the advanced principles or supplement them with others (Ermekbaeva et al., 2018). However, the proposed principles, which are interdependent and implemented in real life, can become a guarantee of effective management of the dairy industry using the potential of the DE and considering possible risks.

The studies of various Russian and foreign researchers show that the theoretical prerequisites for regulating the dairy industry are based on the empirical data (Fadiawati et al., 2019; Suryono et al., 2019; Suieubayeva and Utegenova, 2020; Shebashev et al., 2019). Regulation should be aimed at increasing not only quantitative indicators, but also qualitative ones; therefore, it requires the coverage of the greatest possible number of parameters. Mathematical models of influence of regulatory parameters on the performance of the dairy industry in domestic and foreign sources are not found. In addition, a study of the influence of risks associated with the transformation of the dairy industry to the DE is not found in the analyzed information sources.

The imbalance between the agricultural and service sectors of the dairy industry is the main reason for the continuing decline in livestock and the level of consumption of milk and dairy products per capita. To solve these problems of the dairy industry, digitalization of the government regulation of pricing and product promotion processes from a producer to an end consumer, bypassing intermediaries, is necessary (Prokhorova et al., 2016). Therefore, at the present time, the further development of the dairy industry will be impossible without accelerating the development and effective use of digital technologies (Smolnikova et al., 2019; Luzina et al., 2019; Ziyadin et al., 2019; Goryushkina et al., 2019; Cech et al., 2018; Tadeu et al., 2019).

The analysis of digital technologies along with cognitive technologies made it possible to identify and classify the main risks arising from the transformation of the dairy industry into the DE. During the analysis, a hypothesis was formulated about the possibility of regulating the industry using the DE risk management mechanism.

In general, it should be noted that the digitalization of the dairy sector of the agro-industrial complex is an inevitable necessity for the effective functioning of this economic sector; and for its productive implementation a government policy is needed directed at using the organizational advantages of Russian agriculture. To solve this problem, it is necessary to analyze the existing trends in the government regulation of the digitalization of the dairy industry for making managerial decisions.

\section{Conclusion}

1. An analysis of the dynamics of changes in the number of cows over a 5-year period of time in the Novosibirsk region shows an annual wave-like fluctuation in their numbers with a decrease over the analyzed period within $1 \%$. The main reason of this negative tendency is the presence of intermediaries that create an imbalance between the agricultural and service sectors of the dairy industry. There is also an imbalance between the production and consumption of milk and dairy products per capita. The domestic production in 2014 satisfied only $65 \%$, and in 2018 it satisfied $70 \%$ of consumption. Despite the positive tendency to increase this ratio, its level is insufficient for the potential of the dairy industry of the Novosibirsk region. Solving the challenges of eliminating the existing imbalances is impossible without the effective transformation of the dairy industry to the DE. To implement the transformation process, it is necessary to assess the state of digitalization in the region.

2. The foundations for digitalization in the Novosibirsk region including the dairy industry constitute the following: an information and communication data transmission network with a length of more than 7 thousand $\mathrm{km}$, the main and backup data centers, the state information systems including "GIS of the Novosibirsk region," 


\section{ENTREPRENEURSHIP AND SUSTAINABILITY ISSUES}

ISSN 2345-0282 (online) http://jssidoi.org/jesi/

2020 Volume 7 Number 3 (March)

http://doi.org/10.9770/jesi.2020.7.3(48)

"Government Support of AIC of the Novosibirsk region", "Systems 112," and others. An analysis of responsiveness of the of the milk-producing organizations in the Novosibirsk region to digitalization shows that less than $1 \%$ of them have a high degree of responsiveness, 5-10\% have an average degree of responsiveness, 70$80 \%$ can adapt to digitalization, and 15-20\% are not able to make necessary adaptations on their own. Consequently, most organizations will require a support in the form of various forms of regulation. An analysis of organizations with a high degree of responsiveness to digitalization reveals the possibility of such a transformation process, the effectiveness of which must be analyzed and evaluated.

3. The assessment of the effect of digital technologies on the parameters of the dairy industry reveals a correlation close to linear between the microchipped livestock of cattle and daily milk production per cow and gross milk production. A technological breakthrough in the agricultural sector due to the introduction of digital technologies in agriculture will make it possible to increase labor productivity in agricultural enterprises by 2 times by 2021 . To achieve this goal, it is necessary to develop theoretically substantiated new approaches to the development and practical testing of digital technologies that can solve the tasks.

4. One of the high-priority tasks is the need to develop a non-standard approach to the theoretical foundations of regulating the dairy industry and recommendations for its practical application. The research was based on the methodology of a systemic, integrated, and territorial approaches using the methods of economic interpretation of the results, functional, and comparative analyses. The study is novel in the theoretical justification of a multi-level model of the relationship between the parameters of the dairy industry using the foundations of the synergistic approach. The unusual use of the synergistic effect lies in the hypothesis that there is a relationship between the regulatory impact and the parameters of the dairy industry on the existing functional relationships with it through a multi-level chain of indirect parameter relationships. These parameters have a closer relationship not with the regulator, but with intermediate indicators, and are dependent on it indirectly. The ingenuity of the hypothesis lies in the fact that the correlation coefficient between the regulator and the indirect indicators may be close to zero, but the results obtained will show a high degree of accuracy in their calculation. The proposed approach does not cancel the fundamental mechanisms, laws, theories, and hypotheses developed in the framework of the traditional economy but it organically uses and improves them, which makes it possible to use these approaches as universal in the study of the parameters of the dairy industry, for example, in combination with the simulation modeling.

5. Based on the proposed hypothesis, the developed mathematical model made it possible to use the actual data taken from the open sources and to develop an estimation technique of the effectiveness of indicators of the dairy industry in the Novosibirsk region. The algorithm based on formulas in the form of mathematical support for a digital model obtained by the method of the synergetic approach is rationalized. Moreover, the maximum error does not exceed $10 \%$. Based on the results of developing the digital model and testing its ICT, it can be concluded that it can be used in predicting the development of the dairy industry of the Novosibirsk region depending on the regulatory impact in the form of the invested amount of the government support funds.

6 . The study proposes the method for predicting the parameters of the dairy industry which enables to calculate the parameters of the dairy industry depending on the amount of government support funds. This makes it possible to use regulatory influences to control the development of the dairy industry in the regions. A direct forecast of indicators of the dairy industry in the region is developed. Unlike the existing tools, the forecast is based on the use of not only a time factor but also on the amount of government support funds in three scenarios of the industry development: pessimistic, expected, and optimistic. The study developed a reverse forecast for the necessary volumes of government support to achieve the target indicators of the dairy industry at any level of regulation. 


\section{ENTREPRENEURSHIP AND SUSTAINABILITY ISSUES}

ISSN 2345-0282 (online) http://jssidoi.org/jesi/

2020 Volume 7 Number 3 (March)

http://doi.org/10.9770/jesi.2020.7.3(48)

\section{References}

Almeida, M. V. D. A., Silva, E. M. D., Gomes, N. Â., Nunes, L. A. O., \& Curi, W. F. (2019). Environmental quality of campina grande landfill based on technical and operational aspects. [Qualidade ambiental do aterro sanitário de campina grande com base em aspectos técnicos e operacionais] Periodico Tche Quimica, 16(32), 77-86.

Burda A.G., Burda S.A. (2018). Feasibility of Using an Electronic Dairy Herd Management System in the Context of Digitalization of Economy. Scientific Bulletin of the Yuzhny Institute of Management, 3, 38-43.

Badalyan M.E. (2013). The Principles of Forming the System of Government Regulation of the Agricultural Sector. University Bulletin, 21, $8-15$.

Bobkova, E. Y., Korobejnikova, E. V., Nelyubina, E. G., \& Likhman, V. A. (2015). Pedagogical problems of effective training of specialists in international virtualization of economic industry. Mediterranean Journal of Social Sciences, 6(3S4), 17-24.

https://doi.org/10.5901/mjss.2015.v6n3s4p17

Cech, P., Jindrichovska, I. \& Neubauer, J. 2018. Corporate Social Responsibility in Hotel Industry: Empirical Analysis of Transitional Market. International Journal of Economics \& Business Administration, 6(1), 61-89.

Chernyakov M.K., Chernyakova M.M., Razomasova E.A., Arutyunyan N.V. (2016). Innodiversification. Competitiveness in the Global World: Economics, Science, Technology, 6, 283-287.

Chernyakova M.M. (2019). The Paradoxical Theory of Regulation in the Agricultural Sector (Case Study of the Dairy Industry), edited by M.K. Chernyakova - Novosibirsk: NSTU Publishing House, 160 p.

Chernyakov M.K., Chernyakova M.M. (2018). Directions and Tasks of the Digital Economy of Russia. Modern Trends in Education and Science: State and Prospects: Collection of Materials of International Scientific and Practical Conference Materials in 4 volumes. Edited by Professor G.E. Nakipova and Professor T.A. Khanova. - Karaganda: Karaganda Economic University, p.200-206.

Gritsenko G.M., Chernyakova M.M., Yermakov A.O. (2019). The Essential Model of the System of the Government Regulation of Digitalization of the Dairy Industry. Nauka Krasnoyarsk, 2-3(24-31).

Goryushkina, N., Voinova, N., Voronkova, O., Sitnov, A., Shichiyakh, R., \& Gordeyeva, O. (2019). Theoretical aspects of entrepreneurial education for hospitality industry. Journal of Environmental Management and Tourism, 10(4), 835-841.

https://doi:10.14505/jemt.10.4(36).14

Dunets, A., Latysheva, O., Bitter, N., Vakhrushev, I., Shichiyakh, R., \& Zhuruli, G. (2019). The economic and infrastructural basis for the development of tourist space: The essence, structure and typology. Journal of Environmental Management and Tourism, 10(2), 319-327. https://doi:10.14505/jemt.v10.2(34).05

El Idrissi, N. E. A., Ilham Zerrouk, I., Zirari, N., Monni, S. 2020. Comparative study between two innovative clusters in Morocco and Italy. Insights into Regional Development, 2(1), 400-417. http://doi.org/10.9770/IRD.2020.2.1(1)

Ermakova, A. N., Vaytsekhovskaya, S. S., Malitskaya, V. B., \& Prodanova, N. A. (2016). Investment attractiveness of small innovational business under the conditions of globalization and integration. European Research Studies Journal, 19(2 Special Issue), $258-267$.

Ermekbaeva, B., Supugaliyeva, G., \& Doszhan, R. (2018). Transformation of basic indicators of socio-economic processes in the digital economy. Paper presented at the Proceedings of the 31st International Business Information Management Association Conference, IBIMA 2018: Innovation Management and Education Excellence through Vision 2020, 2009-2017.

Fadiawati, N., Diawati, C., \& Syamsuri, M. M. F. (2019). Constructing a simple distillation apparatus from used goods by using projectbased learning. Periodico Tche Quimica, 16(32), 207-213.

Frolova, I., Voronkova, O., Islamutdinova, D., Gordeyeva, O., Fedulova, I., \& Zhminko, A. (2019). Ecologization of agroindustrial production: Organizational and economic transformations. Journal of Environmental Management and Tourism, 10(3), 622-630. https://doi:10.14505/jemt.v10.3(35).16 


\section{ENTREPRENEURSHIP AND SUSTAINABILITY ISSUES}

ISSN 2345-0282 (online) http://jssidoi.org/jesi/

2020 Volume 7 Number 3 (March)

http://doi.org/10.9770/jesi.2020.7.3(48)

Glotko A.V., Chernyakova M.M., Yermakov A.O. (2019). Analysis of Digitalization Efficiency of the Dairy Industry. Financial Economics, 8(2-3), 15-19.

Hansen, M. F, Smith, M.L., Smith, L.N., Jabbar, K.A. (2019). Forbes Automated Monitoring of Dairy Cow Body Condition, Mobility and Weight Using a Single 3D Video Capture Device. Computers in Industry, 98, 14-22.

Hirdinis, M. 2019. Capital Structure and Firm Size on Firm Value Moderated by Profitability. International Journal of Economics \& Business Administration, 7(1), 174-191.

Kokova E.R. (2019). The Role of Modern Technologies in Ensuring Food Security of the Regions. Bulletin of the Expert Council. 1 (16). URL: https://cyberleninka.ru/article/n/rol-sovremennyh-tehnologiy-v-obespechenii-prodovolstvennoy-bezopasnosti-regionov (accessed: 08.07.2019).

Korableva, O. N., Kalimullina, O. V., \& Mityakova, V. N. (2018). Innovation activity data processing and aggregation based on ontological modelling. Paper presented at the 2018 4th International Conference on Information Management, ICIM 2018 , 1-4. https://doi.org/10.1109/INFOMAN.2018.8392659

Kudryashov V.S., Ryazantsev S.I., Khromykh A.A. (2019). Development of a Combined Digital System for Controlling the Temperature of Cottage Cheese at the Outlet of the Cooler. Devices and Systems. Management, Control, Diagnostics, 2, 28-36.k Sense/ URL:

http://ksense.ru

Livestock Industry Requires the Introduction of Digital Technology. Bulletin of the AIC. URL: http://vestnikapk.ru/articles/aktualno/robotv-pomoshch/

Luzina, T. V., Dudareva, E. A., Akhmetshin, E. M., Prodanova, N. A., Berdova, Y. S., \& Emaletdinova, G. E. (2019). International legal format for trans regionalisation of trade and economic partnership within BRICS in global development. Space and Culture, India, 7(3), 76-85. https://doi.org/10.20896/saci.v7i3.508

Movchan, I. B., \& Yakovleva, A. A. (2019). Refined assessment of seismic microzonation with a priori data optimisation. Journal of Mining Institute, 236, 133-141. https://doi:10.31897/PMI.2019.2.133

Murtazina, D. A., Aleynikova, O. S., Averianova, T. A., \& Aleksiuk, I. O. (2018). Problems of digitalization of higher education in a small town. Paper presented at the Proceedings of the 32nd International Business Information Management Association Conference, IBIMA 2018 - Vision 2020: Sustainable Economic Development and Application of Innovation Management from Regional Expansion to Global Growth, 1710-1716.

Pavlyshyn, L., Voronkova, O., Yakutina, M., \& Tesleva, E. (2019). Ethical problems concerning dialectic interaction of culture and civilization. Journal of Social Studies Education Research, 10(3), 236-248.

Petrenko, Y., Vechkinzova, E., Antonov, V. (2019). Transition from the industrial clusters to the smart specialization of the regions in Kazakhstan. Insights into Regional Development, 1(2), 118-128. https://doi.org/10.9770/ird.2019.1.2(3)

Petrick M., Oshakbaev D. (2015). Kazakhstan's Agricultural Development Constraints: Evidence from the Wheat, Beef and Dairy Sectors. Transition to Agricultural Market Economies: The Future of Kazakhstan, Russia and Ukraine, 15-26.

Plotnikov, A. V., Kuznetsov, P. A., Urasova, A. A. (2018). Digital economy: data analysis on the context advertising market in the UK and the US. International Journal of Civil Engineering and Technology, 9(11), 2372-2382.

Prodani, R., Bushati, J., Andersons, A. 2019. An assessment of impact of information and communication technology in enterprizes of Korça region. Insights into Regional Development, 1(4), 333-342. https://doi.org/10.9770/ird.2019.1.4(4)

Prokhorova, M. P., Prodanova, N. A., Reznichenko, S. M., Vasiliev, V. P., \& Kireev, V. S. (2016). Innovation performance and its influence on enterprise economic efficiency in the market. International Journal of Economics and Financial Issues, 6(8Special Issue), 7883.

PWC — the largest audit network. URL: https://investprofit.info/pwc/

Rightech IoT Cloud. URL: https://rightech.io 


\section{ENTREPRENEURSHIP AND SUSTAINABILITY ISSUES}

ISSN 2345-0282 (online) http://jssidoi.org/jesi/

2020 Volume 7 Number 3 (March)

http://doi.org/10.9770/jesi.2020.7.3(48)

Rahman, P. A. (2017). Analysis of the mean time to data loss of nested disk arrays RAID-01 on basis of a specialized mathematical model. IOP Conference Series: Materials Science and Engineering, 177(1). https://doi.org/10.1088/1757-899X/177/1/012088

Regaña, C., Piñero-Virué, R., \& Reyes-Rebollo, M. (2019). How Multimedia Support Collaborative Research: Best Practices. Research in Social Sciences and Technology, 4(2), 58-72. Retrieved from https://ressat.org/index.php/ressat/article/view/405

Safiullin, M. R., \& Akhmetshin, E. M. (2019). Digital transformation of a university as a factor of ensuring its competitiveness. International Journal of Engineering and Advanced Technology, 9(1), 7387-7390. https://doi:10.35940/ijeat.A3097.109119

Sharafutdinov, R., Gerasimov, V., Akhmetshin, E., Karasik, E., \& Kalimullina, O. (2019). Inclusive development index in Russia: analysis, methods, possibility of application. Revista Genero \& Direito, 8(4), Special Issue, 231-241.

Shebashev, V., Andrianov, Y., Nizova, L., \& Andreeva, E. (2019). Engineers as an object and subject of the development of innovative entrepreneurship at the mesoeconomic level. Journal of Applied Engineering Science, 17(2), 251-255

Smolnikova, F., Tokhtarov, Z., Kenijz, N., Nelyubina, E., Grigoryants, I., Bobkova, E., ... Nikolaeva, N. (2019). Technological process of germination of wheat grain under the water tincture of aloe and its physical-chemical properties. International Journal of Innovative Technology and Exploring Engineering, 9(1), 184-187. https://doi.org/10.35940/ijitee.A3974.119119

Surovtsev V.N., Nikulina Yu.N. (2019). Determining the Economic Efficiency of Various Methods of Keeping Cattle. [Electronic resource]. Access Mode: www.dsx-kirov.ru/new/12-5/5.pptx

Surovtsev V.N. (2015). Announcement of the Study "Assessment of Effectiveness of Implementation of Navigator of the Herd on Russian Farms." The Dairy News. 11/16/2015. Access Mode: http://www.dairynews.com/news/anons-provodimogo-issledovaniyaotsenkaeffektivno.html

Sysuev V.A., Vasilenko T.F., Rusakov R.V. (2017). Problems of Developing Dairy Animal Husbandry in Russia and Modern Approaches to Their Solution. Achievements of Science and Technology of the Agricultural Sector = Dostizheniya Nauki i Tekhniki APK, 31(3), 20-24.

Sycheva, I. N., Voronkova, O. Y., Kovaleva, I. V., Kuzina, A. F., Bannikov, S. A., \& Titova, S. V. (2019). Motivation in personnel management of a trading enterprise. International Journal of Economics and Business Administration, 7, 570-582.

Suieubayeva, S., \& Utegenova, A. (2020). Digital transformation in business. Lecture Notes in Networks and Systems, 84, 408-415. https://doi:10.1007/978-3-030-27015-5_49

Suryono, S., Surarso, B., Saputra, R., \& Sudalma, S. (2019). Real-time decision support system for carbon monoxide threat warning using online expert system. Journal of Applied Engineering Science, 17(1), 18-25.

Tadeu, P., Fernandez Batanero, J., \& Tarman, B. (2019). ICT in a Global World. Research in Social Sciences and Technology, 4(2), i-ii. Retrieved from https://ressat.org/index.php/ressat/article/view/431

Tultabayeva, T., Chomanov, U., Kenenbay, G., Zhumaliyeva, G., \& Shoman, A. (2019). Formulation of multicomponent mixture in the production of combined soft cheese. Journal of Hygienic Engineering and Design, 29, 125-131.

Tultabayeva, T., Chomanov, U., Tultabayev, B., Shoman, A., Zhonyssova, M., \& Aitimova, D. (2017). Main features of freezing of mare's milk. Journal of Engineering and Applied Sciences, 12(13), 3319-3322. https://doi:10.3923/jeasci.2017.3319.3322

The Ministry of Agriculture of the Russian Federation: Materials of the 5th International Agro-Industrial Dairy Forum "Digital Agenda for the Dairy Industry" [Electronic resource] - Access mode: http://mcx.ru/press-service/news/minselkhoz-rossii-predstavil-proekt-tsifrovoe$\underline{\text { selskoe-khozyaystvo }}$

Tikhonov, A. I., Sazonov, A. A., \& Novikov, S. V. (2019). Digital aviation industry in Russia. Russian Engineering Research, 39(4), 349353. https://doi:10.3103/S1068798X19040178

Trofimova, L., Prodanova, N., Korshunova, L., Savina, N., Ulianova, N., Karpova, T., \& Shilova, L. (2019). Public sector entities' reporting and accounting information system. Journal of Advanced Research in Dynamical and Control Systems, 11(8 Special Issue), 416424.

Volkova E. (2013). Computer and Herd. Agricultural Machinery and Technology. No. 1. [Electronic resource]. Access mode: http://www.agroinvestor.ru/technologies/article/15027-kompyuter-i-stado 


\section{ENTREPRENEURSHIP AND SUSTAINABILITY ISSUES}

ISSN 2345-0282 (online) http://jssidoi.org/jesi/

2020 Volume 7 Number 3 (March)

http://doi.org/10.9770/jesi.2020.7.3(48)

Yandex Zen. URL: https://zen.yandex.ru/media/e-xecutive.ru/chto-takoe-cifrovizaciia-5c18d1a1e2f26100aaeaf9fa

Yemelyanov, V., Yemelyanova, N., \& Nedelkin, A. (2018). Diagnostic system to determine lining condition. Paper presented at the MATEC Web of Conferences, 172 https://doi:10.1051/matecconf/201817204001

Ziyadin, S., Litvishko, O., Dubrova, M., Smagulova, G., \& Suyunchaliyeva, M. (2019). Diversification tourism in the conditions of the digitalization. International Journal of Civil Engineering and Technology, 10(2), 1055-1070.

Andrei GLOTKO, Gorno-Altaisk State University, Gorno-Altaisk, Russian Federation. Doctor of Economics, Associate Professor. Research interest: Economy of agriculture.

ORCID ID: http://orcid.org/0000-0002-0160-6392

Aleksandra POLYAKOVA, Doctor of Economic Sciences, Professor of Economics, PhD (econ.), holds a chair in Economics and Production Setup at Industrial University of Tyumen and leads research Plekhanov Russian University of Economics. She has experience and expertise in data-driven analytical systems design, investment appraisal and deployment, regional development and strategic management. Prof. Polyakova has a significant back-track in advisory services for the federal and regional authorities on the matters of economic policy improvement and public administration. Research interests: regional studies, innovations deployment, investment appraisal, Big Data analysis and systems design.

ORCID ID: http://orcid.org/0000-0002-3674-4111

Mariya KUZNETSOVA, Senior Lecturer, Professor of the Department of propaedeutics of dental diseases of the Institute of Dentistry of Sechenov University. Currently engaged in teaching dentistry, as well as conducts research in the field of management, corporate reporting. Research interests: management in dentistry, internal control systems, introduction of digital technologies.

ORCID ID: $\underline{\text { http://orcid.org/0000-0002-5488-8979 }}$

Kseniya KOVALENKO, Ph.D in Law, associate professor of labor, environmental law and civil process Department of Law institute, Altai State University.

Expert in the theory of state and law, legal regulation of entrepreneurship, problems of administrative offenses.

Research interests: jurisprudence, digitalization of business processes, big data analysis.

ORCID ID: http://orcid.org/0000-0001-6017-8933

Rustem SHICHIYAKH, Ph.D. (Econ.), Associate professor, Department of Management, Kuban State Agrarian University named after I.T. Trubilin. Expert in the field of state regulation of agriculture and sustainable tourism development.

Research interests: state regulation of the economy, agriculture, sustainable development of tourism, rural areas, management, human capital, entrepreneurship

ORCID ID: $\underline{\text { http://orcid.org/0000-0002-5159-4350 }}$

Margarita MELNIK PhD in Economics, professor of accounting, analysis and audit Department, Financial University under the Government of the Russian Federation. Expert in the theory and methodology of economic analysis, control and audit. Research interests: state management system, audit development concept, innovation management

ORCID ID: $\underline{\text { http://orcid.org/0000-0002-7428-9535 }}$

Register for an ORCID ID:

https://orcid.org/register

Copyright (C) 2020 by author(s) and VsI Entrepreneurship and Sustainability Center

This work is licensed under the Creative Commons Attribution International License (CC BY).

http://creativecommons.org/licenses/by/4.0/

cC) (i) Open Access 